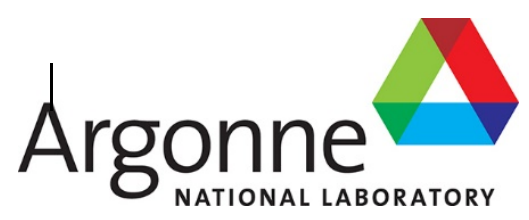

ANL-ART-149

\title{
OPTD: Out-of-Pile Transient Database
}

Nuclear Engineering Division 


\section{About Argonne National Laboratory}

Argonne is a U.S. Department of Energy laboratory managed by UChicago Argonne, LLC under contract DE-AC02-06CH11357. The Laboratory's main facility is outside Chicago, at 9700 South Cass Avenue, Argonne, Illinois 60439. For information about Argonne and its pioneering science and technology programs, see www.anl.gov.

\section{DOCUMENT AVAILABILITY}

Online Access: U.S. Department of Energy (DOE) reports produced after 1991 and a growing number of pre-1991 documents are available free at OSTI.GOV

(http://www.osti.gov/), a service of the U.S. Dept. of Energy's Office of Scientific and

Technical Information

Reports not in digital format may be purchased by the public from the

National Technical Information Service (NTIS):

U.S. Department of Commerce

National Technical Information Service

5301 Shawnee Rd

Alexandria, VA 22312

www.ntis.gov

Phone: (800) 553-NTIS (6847) or (703)

605-6000 Fax: (703) 605-6900

Email: orders@ntis.gov

Reports not in digital format are available to DOE and DOE contractors from the Office of Scientific and Technical Information (OSTI):

U.S. Department of Energy

Office of Scientific and Technical Information

P.O. Box 62

Oak Ridge, TN 37831-0062

www.osti.gov

Phone: (865) 576-8401

Fax: (865) 576-5728

Email: reports@osti.gov

\section{Disclaimer}

This report was prepared as an account of work sponsored by an agency of the United States Government. Neither the United States Government nor any agency thereof, nor UChicago Argonne, LLC, nor any of their employees or officers, makes any warranty, express or implied, or assumes any legal liability or responsibility for the accuracy, completeness, or usefulness of any information, apparatus, product, or process disclosed, or represents that its use would not infringe privately owned rights. Reference herein to any specific commercial product, process, or service by trade name, trademark, manufacturer, or otherwise, does not necessarily constitute or imply its endorsement, recommendation, or favoring by the United States Government or any agency thereof. The views and opinions of document authors expressed herein do not necessarily state or reflect those of the United States Government or any agency thereof, Argonne National Laboratory, or UChicago Argonne, LLC. 


\section{OPTD: Out-of-Pile Transient Database}

prepared by

Carolyn Tomchik and Aaron Oaks

Nuclear Engineering Division, Argonne National Laboratory

September 30, 2018 


\section{Summary}

\section{OPTD: Out-of-Pile Transient Database}

The DOE Advanced Reactor Technology program has supported knowledge preservation efforts to recover and preserve fuel data from the US sodium cooled fast reactor (SFR) program. Efforts have focused on establishing databases of experimental data generated during the Integral Fast Reactor program (at EBR-II, FFTF, and TREAT) as well as during related out-of-pile examinations of the fuel irradiated at EBR-II. The information in these databases is essential to support further development and licensing activities for advanced fast reactor designs. OPTD, a newly-created database of out-of-pile furnace transient tests on metallic fuel, includes records of 62 tests on irradiated fuel pins conducted in furnace apparatuses constructed in the Alpha-Gamma Hot Cell Facility at ANL. Record discovery is ongoing, and at present, the database includes hundreds of documents describing these tests and related results. Access is currently available to Department of Energy researchers and can be extended to members of industry and the public as the content is approved for distribution. This report describes the out-of-pile furnace testing program, the content available in the database, and the structure of the web-accessible interface. 


\section{CONTENTS}

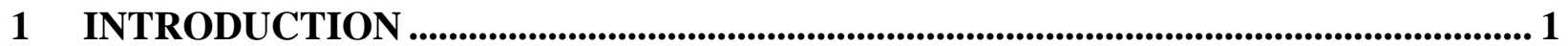

$1.1 \quad$ Fuel Compatibility Tests ......................................................................................... 1

$1.2 \quad$ Furnace Transient Test Procedures ....................................................................... 2

1.3 Motivation for a Database .......................................................................................... 3

2 OUT-OF-PILE FURNACE TESTING PROGRAM........................................................... 4

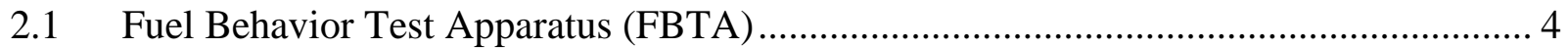

2.1.1 FBTA Experimental Procedures ………………………………………………...... 4

2.1.2 FBTA Fuel Compatibility Test Matrix ………………………………………........ 5

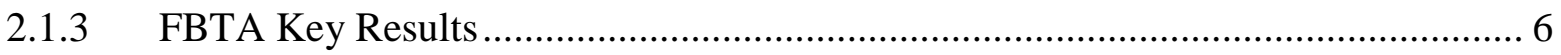

$2.2 \quad$ Whole Pin Furnace (WPF) ...................................................................................... 7

2.2.1 WPF Experimental Procedures .......................................................................... 8

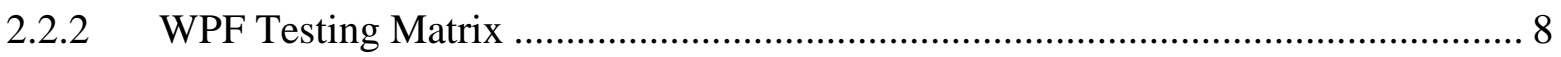

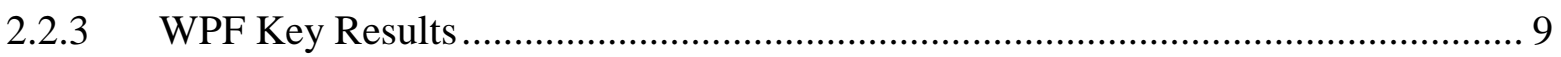

2.3 Summary Results of Out-of-Pile testing program..................................................... 10

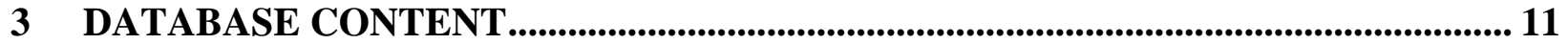

4 DATABASE STRUCTURE ............................................................................................ 13

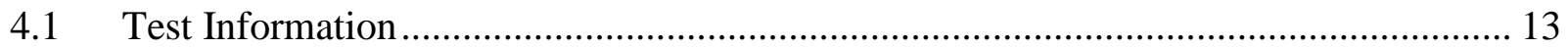

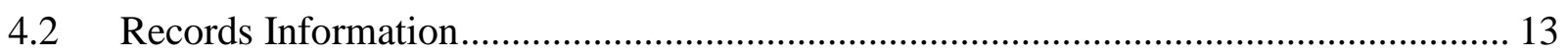

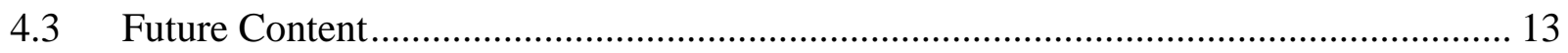

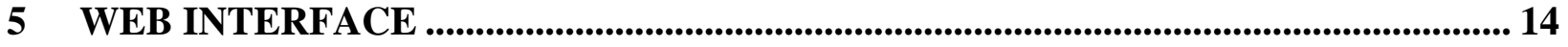

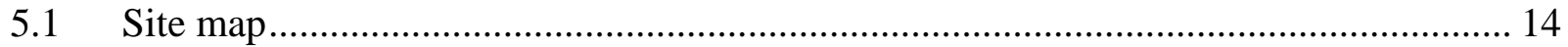

5.2 Access Controls ................................................................................................. 14

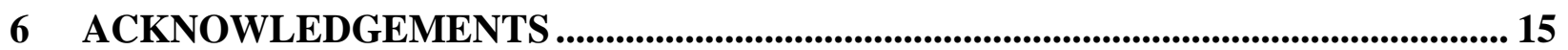

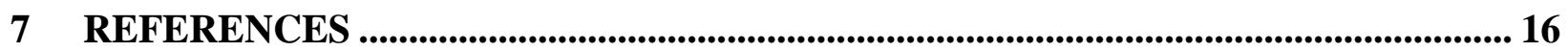




\section{INTRODUCTION}

The Integral Fast Reactor (IFR) program, active from 1984 to 1994, produced a large collection of data relating to the performance of metallic fuels in sodium-cooled fast reactors (SFRs). To evaluate fuel/cladding compatibility, tests were conducted under both steady-state and transient conditions. Steady-state tests were first conducted within test reactors to evaluate fuel performance during normal reactor operating conditions. During steady-state reactor operation, solid state interdiffusion at the fuel-cladding interface within a fuel pin causes slight cladding wastage, which is highly dependent on the local power, temperature, and burnup of the fuel. While this wastage is not a concern under normal operating conditions, the metallic fuel pin may be more vulnerable to off-normal events (e.g., loss of coolant flow, loss of a heat sink, or transient overpower events). Transient tests are then needed to evaluate fuel performance during these off-normal events. During these transient scenarios, the fuel pin will experience elevated temperatures, at which uranium and plutonium from the fuel can react with iron and other components in the cladding, forming liquid phases (eutectic formation). The eutectic formation at the fuel-clad interface reduce the cladding thickness and may compromise its integrity. While these off-normal events can be simulated in-pile (e.g., in the TREAT reactor), they can also be simulated out-of-pile by raising fuel samples rapidly to high temperatures representative of these accident scenarios. The transient testing conducted in the Alpha-Gamma Hot Cell Facility (AGHCF) used irradiated fuel samples from EBR-II with fuel-clad interfaces prototypic of those found in an operating reactor.

\subsection{Fuel Compatibility Tests}

For a clearer picture of where the AGHCF furnace transient tests fit in the larger landscape of IFR fuel compatibility testing, they can be compared to both the transient testing conducted in TREAT and the steady-state testing conducted in EBR-II. The tests of metallic fuels conducted in EBR-II were lower temperature, steady-state tests to demonstrate the performance of the fuel under normal operating conditions. Records of these EBR-II tests can be found in FIPD [1] and PADB [2]. An extensive long-duration transient testing program was also conducted at EBR-II as documented in another safety testing database [3]. The transient tests conducted on metallic fuels in the TREAT reactor were high temperature, short duration transient tests to demonstrate the fuel behavior under rapid transient conditions, and their records are found in the TREXR database [4]. The AGHCF furnace tests described herein bridge the gap between the EBR-II and TREAT testing conditions; they exposed irradiated fuel samples to elevated, accident-scenario temperatures for times in the range of minutes to hours, as shown in Figure 1. 


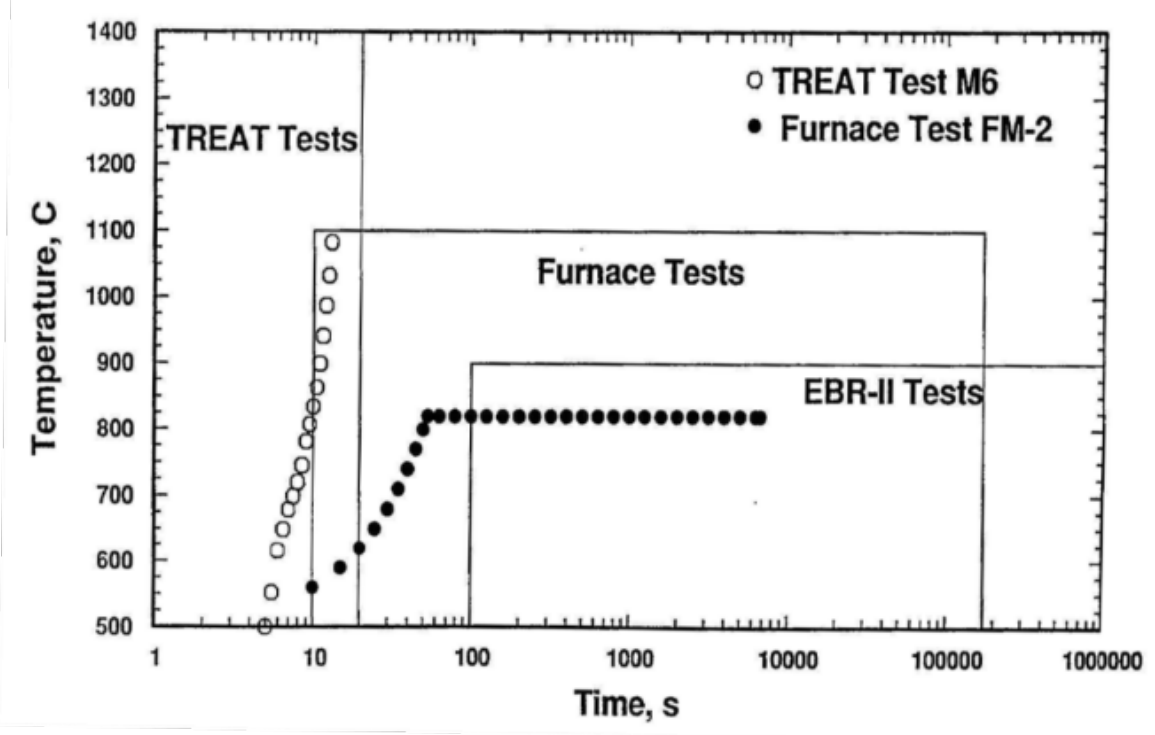

Figure 1: Testing regimes for in-reactor and out-of-pile tests on metallic fuels [5].

\subsection{Furnace Transient Test Procedures}

The anatomy of a furnace transient test is described here. Before the testing routine began, pre-test examinations of the fuel and cladding were made to characterize the as-irradiated structure. To begin the temperature transient test, the sample was installed in the furnace and slowly ramped to a pre-test, priming temperature. When the prescribed furnace transient routine was run, the temperature was increased at a predetermined rate (ramp rate) to a peak target temperature. A representative furnace testing routine is shown in Figure 2. The ramp rate was selected in order to give a rapid temperature rise but minimize the temperature overshoot at the peak. The sample was held at the target temperature for a designated period of time or until pin failure. The furnace was scrammed when the test end condition was met (either at the end of the test time, or when pin failure was detected by a pressure spike), and the pin was then allowed to cool by convective heat loss. Figure 2 shows a temperature history as a sample was ramped from the pre-test priming temperature up to the target temperature with a minimal temperature overshoot (at point a) and held at the target temperature until the pressure transducers detected failure in the pin causing the furnace to scram (point b). Following the test, data was collected and post-test examinations were made of the sample. 


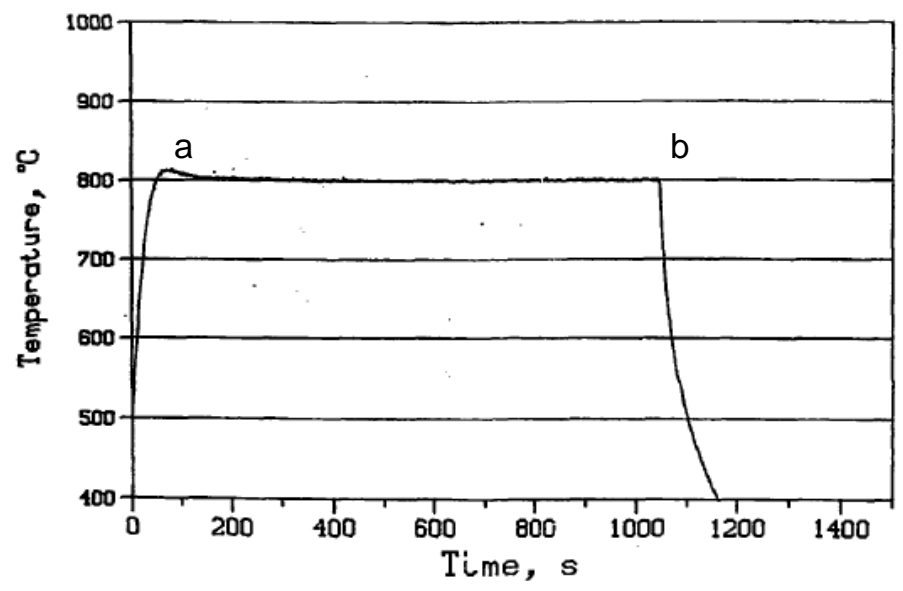

Figure 2: Furnace testing routine [6].

\subsection{Motivation for a Database}

Documentation of the furnace tests was scattered, and found in a variety of locations ranging from private offices to file cabinets in storage areas. Much of the recorded information about the tests, particularly lessons learned and comments relating to design of the tests, does not exist in the formal reports, but rather in informal, internal memos and notes. Without an effort to digitally archive these documents, they may have been lost to time. Including these records in a linked digital archive allows a user to see all of the relevant documents for a particular test collected together, giving the most complete context for understanding the test and results. The database described in this report will provide a means for an interested person to go about locating and accessing the records they need from the collection. 


\section{OUT-OF-PILE FURNACE TESTING PROGRAM}

This section describes the out-of-pile furnace testing experiments conducted at the AGHCF under the IFR program. These were overheating tests conducted on irradiated fuels using a furnace housed in a hot cell. The first furnace apparatus built in the AGHCF for testing irradiated fuel samples was the Direct Electrical Heating (DEH) apparatus; it was a predecessor to those described here. Since the DEH tests were conducted on U-Fs (uranium-fissium alloy) samples, there is less interest in them, and thus less interest in archiving the related records. However, if and when the relevant records are located, they could be added to the database in the future. The two most recent experimental setups used for the out-of-pile transient testing of metallic fuels are described here.

\subsection{Fuel Behavior Test Apparatus (FBTA)}

The Fuel Behavior Test Apparatus (FBTA) was built as an improvement of the DEH apparatus. It replaced the ohmic internal heating of the DEH experiments with external radiant heating using an elliptical furnace. It was used to test segments of fuel from EBR-II for fuel-cladding compatibility, to reveal the mechanisms and kinetics of the fuel-clad eutectic interaction, and determine the resulting depth of liquid phase cladding penetration. Information was also collected on the fuel dimensional stability and the quantity and rate of fission gas release. A schematic of the FBTA setup as well as an image of the furnace are shown in Figure 3.

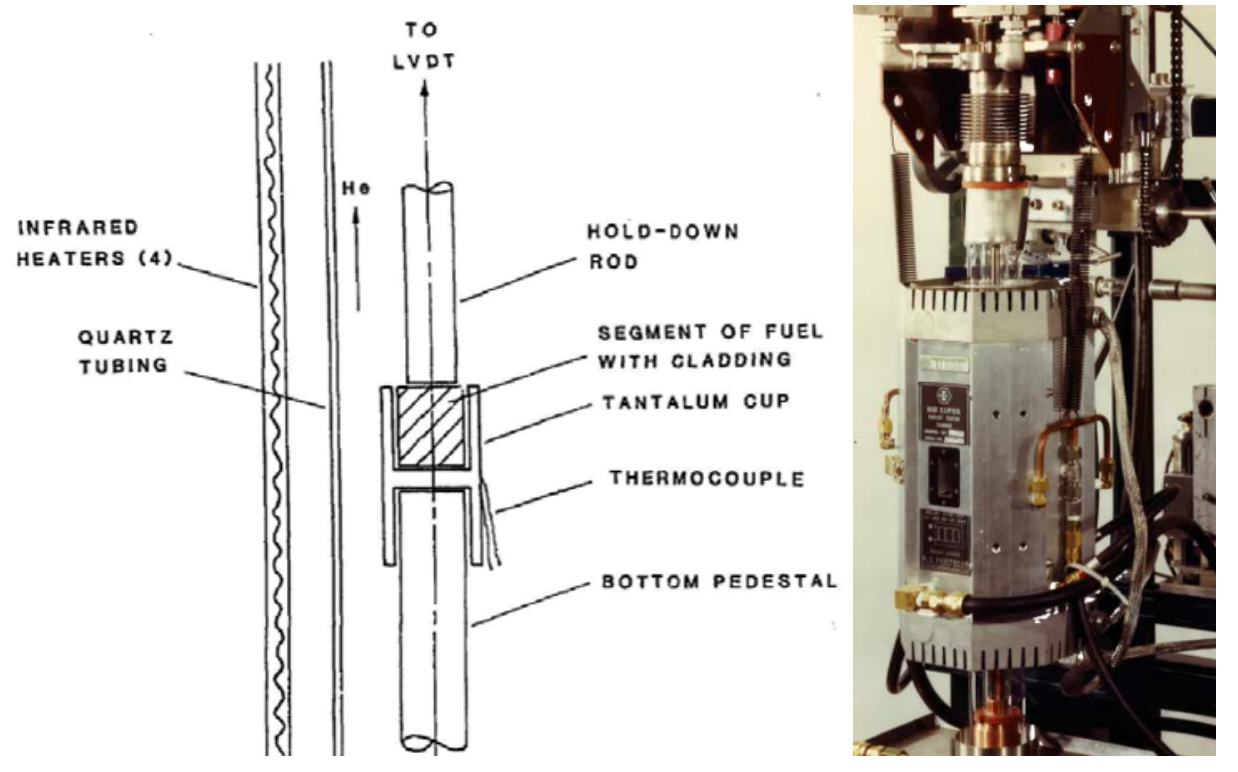

Figure 3: The Fuel Behavior Test Apparatus (FBTA) [7].

\subsubsection{FBTA Experimental Procedures}

The samples tested in the FBTA were typically fuel/clad segments $~ 8 \mathrm{~mm}$ tall, held in a $10 \mathrm{~mm}$ deep tantalum holding cup. A tantalum hold-down rod placed on top of the fuel segment was 
connected to a linear variable differential transformer (LVDT) to measure dimensional changes in the sample. The sample holder was housed inside two concentric quartz tubes with high-purity helium flow, providing an inert atmosphere for the test. Computer control of the furnace was driven by a thermocouple welded to the sample holder, and resulted in temperature fluctuations that were generally less than $3^{\circ} \mathrm{C}$. A video port enabled high speed film recording of the experiments. The furnace itself was comprised of four longitudinal infrared bulbs with elliptical reflectors to focus the radiant heat. This setup provided a $\sim 10^{\prime}$ uniform heating zone along the centerline, within which the sample was placed. Ramp rates of up to $30^{\circ} \mathrm{C} / \mathrm{s}$ were achievable, but $10{ }^{\circ} \mathrm{C} / \mathrm{s}$ was used in order to minimize target temperature overshoot. Samples were heated to the designated testing temperature, held for testing times ranging from a few minutes to 7 hours, then the furnace was scrammed. The samples cooled to under $500{ }^{\circ} \mathrm{C}$ within 30 seconds.

During the test, fission-gas detection was routinely done using a downstream, out-of-cell ionization chamber for real-time monitoring of ${ }^{85} \mathrm{Kr}$. Collection of $\mathrm{Xe}$ and $\mathrm{Kr}$ gas release for volumetric measurement and mass spectrographic analysis was also done on some samples. The LVDT monitored the change in specimen length due to fission gas-induced swelling, phase transformation, and liquefaction.

Before and after the transient tests, high-magnification imaging of all specimens was performed in order to determine the maximum depth of cladding penetration. Scanning electron microscopy, Energy-dispersive X-ray spectroscopy, and/or shielded electron microprobe examinations were made of several specimens to identify phases in the fuel-cladding interaction zone. Some samples were etched for detailed comparison of the microstructure of the reacted vs. unreacted cladding. Comparative microhardness measurements were taken of the reacted and unreacted areas of some samples. For samples where fission gasses were collected during the test, the collected gas could also be analyzed following the test.

\subsubsection{FBTA Fuel Compatibility Test Matrix}

Table 1 shows the full test matrix for the FBTA. More than 50 tests were performed on segments extracted from various locations along the length of EBR-II fuel pins. Tests were done at constant

temperatures ranging from 700 to $850^{\circ} \mathrm{C}$ and held at temperatures for durations from a few minutes up to 7 hours (though most were conducted with a $1 \mathrm{hr}$ duration). Fuels tested were U-10Zr and ternary fuels (up to U-26Pu-10Zr), with claddings composed of HT9, D9, or 316 stainless steel. Samples had peak burnups ranging from 3 to $17 \%$. 


\begin{tabular}{|c|c|c|c|c|c|c|c|}
\hline $\begin{array}{l}\text { Test } \\
\text { No. }\end{array}$ & Fuel/Cladding & Pin \# & S/A & $\begin{array}{c}\text { Peak } \\
\text { B/U } \\
(a / o)\end{array}$ & $\begin{array}{l}\text { axial } \\
\text { loc'n } \\
(x / L)\end{array}$ & $\begin{array}{c}\text { Test } \\
\text { Temp } \\
\left({ }^{\circ} \mathrm{C}\right)\end{array}$ & $\begin{array}{c}\text { Test } \\
\text { Time } \\
\text { (h) }\end{array}$ \\
\hline $87-74$ & U-19Pu-10Zr/HT9 & T459 & $\mathrm{X} 425$ & 3 & 0.69 & 700 & 1.0 \\
\hline $87-75$ & U-19Pu-10Zr/HT9 & T459 & $\mathrm{X} 425$ & 3 & 0.71 & 750 & 1.0 \\
\hline $87-76$ & U-19Pu-10Zr/HT9 & T459 & $\mathrm{X} 425$ & 3 & 0.74 & 780 & 1.0 \\
\hline $88-01$ & U-10Zr/HT9 & T437 & $X 425$ & 3 & 0.85 & 800 & 1.0 \\
\hline $88-02$ & U-10Zr/HT9 & T437 & $\mathrm{X} 425$ & 3 & 0.87 & 850 & 1.0 \\
\hline $88-03$ & $\mathrm{U}-10 \mathrm{Zr} / \mathrm{HT} 9$ & T437 & $\mathrm{X} 425$ & 3 & 0.89 & 750 & 1.0 \\
\hline $88-04$ & U-10Zr/HT9 & T437 & $\mathrm{X} 425$ & 3 & 0.46 & 800 & 1.0 \\
\hline $88-05$ & U-10Zr/HT9 & T437 & $\mathrm{X} 425$ & 3 & 0.48 & 750 & 1.0 \\
\hline $88-06$ & $\mathrm{U}-10 \mathrm{Zr} / \mathrm{HT} 9$ & T437 & $\mathrm{X} 425$ & 3 & 0.52 & 700 & 1.0 \\
\hline $88-13$ & $\mathrm{U}-10 \mathrm{Zr} / \mathrm{HT}$ & T437 & $\mathrm{X} 425$ & 3 & 0.56 & 725 & 1.0 \\
\hline $88-07$ & U-10Zr/D9 & T224 & $\mathrm{X} 420$ & 6 & 0.93 & 800 & 1.0 \\
\hline $88-08$ & $\mathrm{U}-10 \mathrm{Zr} / \mathrm{Dg}$ & T224 & $\mathrm{X} 420$ & 6 & 0.91 & 750 & 1.0 \\
\hline $88-09$ & U-10Zr/D9 & T224 & $\mathrm{X} 420$ & 6 & 0.89 & 725 & 1.0 \\
\hline $88-11$ & $\mathrm{U}-10 \mathrm{Zr} / \mathrm{D9}$ & T248 & $\mathrm{X} 421$ & 10 & 0.76 & 750 & 1.0 \\
\hline $88-12$ & $\mathrm{U}-10 \mathrm{Zr} / \mathrm{D9}$ & $\mathrm{T} 248$ & $\mathrm{X} 421$ & 10 & 0.78 & 800 & 1.0 \\
\hline $88-14$ & U-10Zr/D9 & T248 & $\mathrm{X} 421$ & 10 & 0.74 & 800 & 1.0 \\
\hline $88-15$ & $\mathrm{U}-10 \mathrm{Zr} / \mathrm{HT} 9$ & T619 & X429 & 8 & 0.46 & 800 & 1.0 \\
\hline $88-16$ & U-10Zr/HT9 & T619 & $\times 429$ & 8 & 0.55 & 800 & 0.5 \\
\hline $88-17$ & U-10Zr/HT9 & T619 & X429 & 8 & 0.23 & 800 & 2.0 \\
\hline $88-18$ & $\mathrm{U}-10 \mathrm{Zr} / \mathrm{HT} 9$ & T619 & $\times 429$ & 8 & 0.2 & 800 & 1.0 \\
\hline $88-19$ & $\mathrm{U}-10 \mathrm{Zr} / \mathrm{HTS}$ & T619 & X429 & 8 & 0.25 & 800 & 0.5 \\
\hline $88-20$ & U-10Zr/HT9 & T619 & X429 & 8 & 0.27 & 800 & 0.1 \\
\hline $88-21$ & U-10Zr/HT9 & T619 & $\times 429$ & 8 & 0.3 & 800 & 0.2 \\
\hline $88-22$ & U-26Pu-10Zr/316 & T326 & $\mathrm{X} 423$ & 5 & 0.54 & 700 & 1.0 \\
\hline $88-23$ & U-26Pu-10Zr/316 & T326 & $\mathrm{X} 423$ & 5 & 0.6 & 750 & 1.0 \\
\hline $88-24$ & $\mathrm{U}-26 \mathrm{Pu}-10 \mathrm{Zr} / 316$ & T326 & X423 & 5 & 0.57 & 800 & 1.0 \\
\hline $88-25$ & U-26Pu-10Zr/316 & T326 & $\mathrm{X} 423$ & 5 & 0.45 & 670 & 7.0 \\
\hline $88-27$ & $\mathrm{U}-26 \mathrm{Pu}-10 \mathrm{Zr} / 316$ & T326 & $\mathrm{X} 423$ & 5 & 0.48 & 740 & 7.0 \\
\hline
\end{tabular}

\begin{tabular}{cccccccc}
\hline $\begin{array}{c}\text { Test } \\
\text { No. }\end{array}$ & Fuel/Cladding & Pin \# & S/A & $\begin{array}{c}\text { Peak } \\
\text { B/U } \\
\text { (a/o) }\end{array}$ & $\begin{array}{c}\text { axial } \\
\text { loc'n } \\
\text { (x/L) }\end{array}$ & $\begin{array}{c}\text { Test } \\
\text { Temp } \\
\text { ('C) }\end{array}$ & $\begin{array}{c}\text { Test } \\
\text { Time } \\
\text { (h) }\end{array}$ \\
\hline $88-26$ & U-26Pu-10Zr/316 & T326 & X423 & 5 & 0.63 & 850 & 1.0 \\
$88-27$ & U-26Pu-10Zr/316 & T326 & X423 & 5 & 0.48 & 740 & 7.0 \\
$88-28$ & U-26Pu-10Zr/316 & T326 & X423 & 5 & 0.4 & 710 & 7.0 \\
$89-01$ & U-26Pu-10Zr/316 & T326 & X423 & 5 & 0.42 & 770 & 7.0 \\
$89-02$ & U-10Zr/316SS & T536 & X421 & 9 & 0.48 & 800 & 1.0 \\
$89-03$ & U-10Zr/316SS & T536 & X421 & 9 & 0.52 & 850 & 1.0 \\
$89-04$ & U-10Zr/316SS & T536 & X421 & 9 & 0.45 & 750 & 1.0 \\
$89-05$ & U-10Zr/316SS & T323 & X423 & 5 & 0.55 & 800 & 1.0 \\
$89-06$ & U-10Zr/316SS & T536 & X421 & 5 & 0.52 & 750 & 1.0 \\
$89-08$ & U-10Zr/316SS & T536 & X421 & 5 & 0.45 & 850 & 1.0 \\
$89-13$ & U-10Zr/316SS & T536 & X421 & 5 & 0.58 & 800 & 0.4 \\
$89-14$ & U-10Zr/316SS & T536 & X421 & 5 & 0.61 & 800 & 0.2 \\
$89-15$ & U-10Zr/316SS & T536 & X421 & 5 & 0.64 & 800 & 2.0 \\
$89-16$ & U-10Zr/316SS & T536 & X421 & 5 & 0.67 & 800 & 4.0 \\
$89-09$ & U-26Pu-10Zr/316 & T326 & X423 & 5 & 0.7 & 800 & 1.0 \\
$89-10$ & U-26Pu-10Zr/316 & T326 & X423 & 5 & 0.73 & 800 & 2.0 \\
$89-11$ & U-26Pu-10Zr/316 & T326 & X423 & 5 & 0.78 & 800 & 4.0 \\
$89-12$ & U-26Pu-10Zr/316 & T326 & X423 & 5 & 0.8 & 800 & 0.4 \\
$90-01$ & U-19Pu-10Zr/D9 & T106 & X421 & 17 & 0.5 & 750 & 1.0 \\
$90-02$ & U-19Pu-10Zr/D9 & T106 & X421 & 17 & 0.87 & 750 & 1.0 \\
$90-03$ & U-19Pu-10Zr/D9 & T106 & X421 & 17 & 0.84 & 800 & 1.0 \\
$90-04$ & U-10Zr/D9 & T227 & X421 & 17 & 0.51 & 800 & 1.0 \\
$90-05$ & U-10Zr/D9 & T227 & X421 & 17 & 0.87 & 800 & 1.0 \\
$90-06$ & U-10Zr/D9 & T227 & X421 & 17 & 0.53 & 800 & 1.0 \\
$90-07$ & U-10Zr/D9 & T227 & X421 & 17 & 0.82 & 750 & 1.0 \\
$90-08$ & U-10Zr/D9 & T227 & X421 & 17 & 0.78 & 725 & 1.0 \\
$90-09$ & U-10Zr/D9 & T227 & X421 & 17 & 0.75 & 800 & 0.5 \\
$90-10$ & U-10Zr/D9 & T227 & X421 & 17 & 0.73 & 725 & 7.0 \\
\hline & & & & & & &
\end{tabular}

Table 1: FBTA Fuel Compatibility Test Matrix [8].

\subsubsection{FBTA Key Results}

The post-test metallography revealed the boundary of cladding penetration for each sample. The thickness of the thinnest portion of the remaining cladding was measured for each specimen, and the maximum cladding penetration was calculated as the difference between the original cladding thickness and the thinnest remaining cladding. The results of the FBTA tests established the timeand temperature-dependence of the eutectic cladding penetration. Tests conducted at $800^{\circ} \mathrm{C}$ for varying durations ( 7 minutes to 2 hours) found that after the initial rapid reaction, the rate of cladding penetration by eutectic formation is largely time-independent (it either remains constant or decreases slightly with time). Temperature dependence of liquid-phase penetration, determined by a series of 1 hour transients at different temperatures, shows an Arrhenius correlation, shown in Figure 4. For a given set of FBTA test conditions, higher burnup samples have a lower threshold temperature for eutectic formation. 


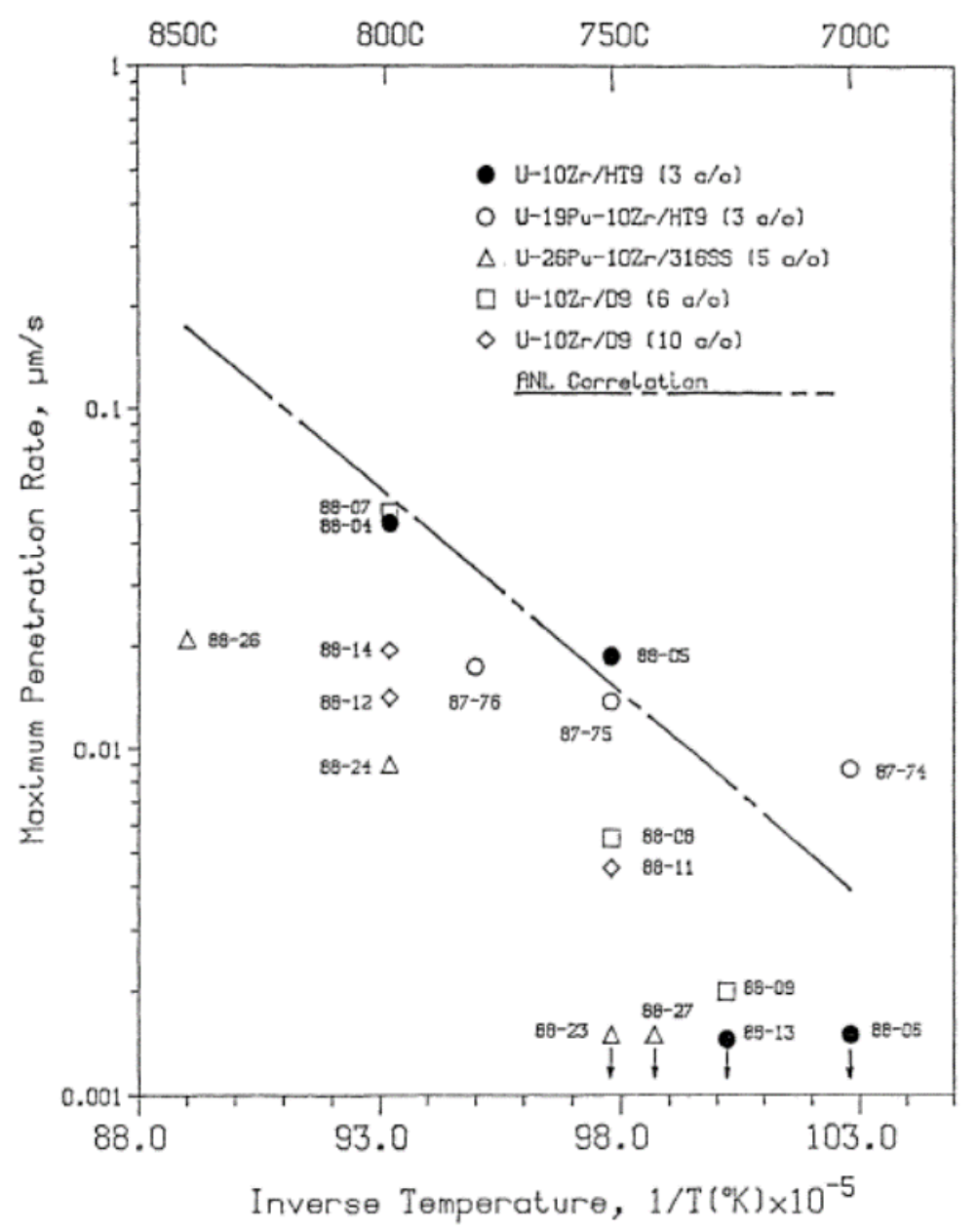

Figure 4: Temperature-dependent eutectic cladding penetration rate, from [9].

\subsection{Whole Pin Furnace (WPF)}

The Whole Pin Furnace (WPF) was built to allow for testing of intact fuel pins from EBR-II, rather than segments, to study synergistic effects of fission gas pressure loading and fuel-cladding interaction. It was used to determine modes of pin failure, establish safety margins and fuel failure thresholds, and examine fuel motion within the pin. It also used external radiant heating from an elliptical furnace. A schematic of the WPF setup is shown in Figure 5. 

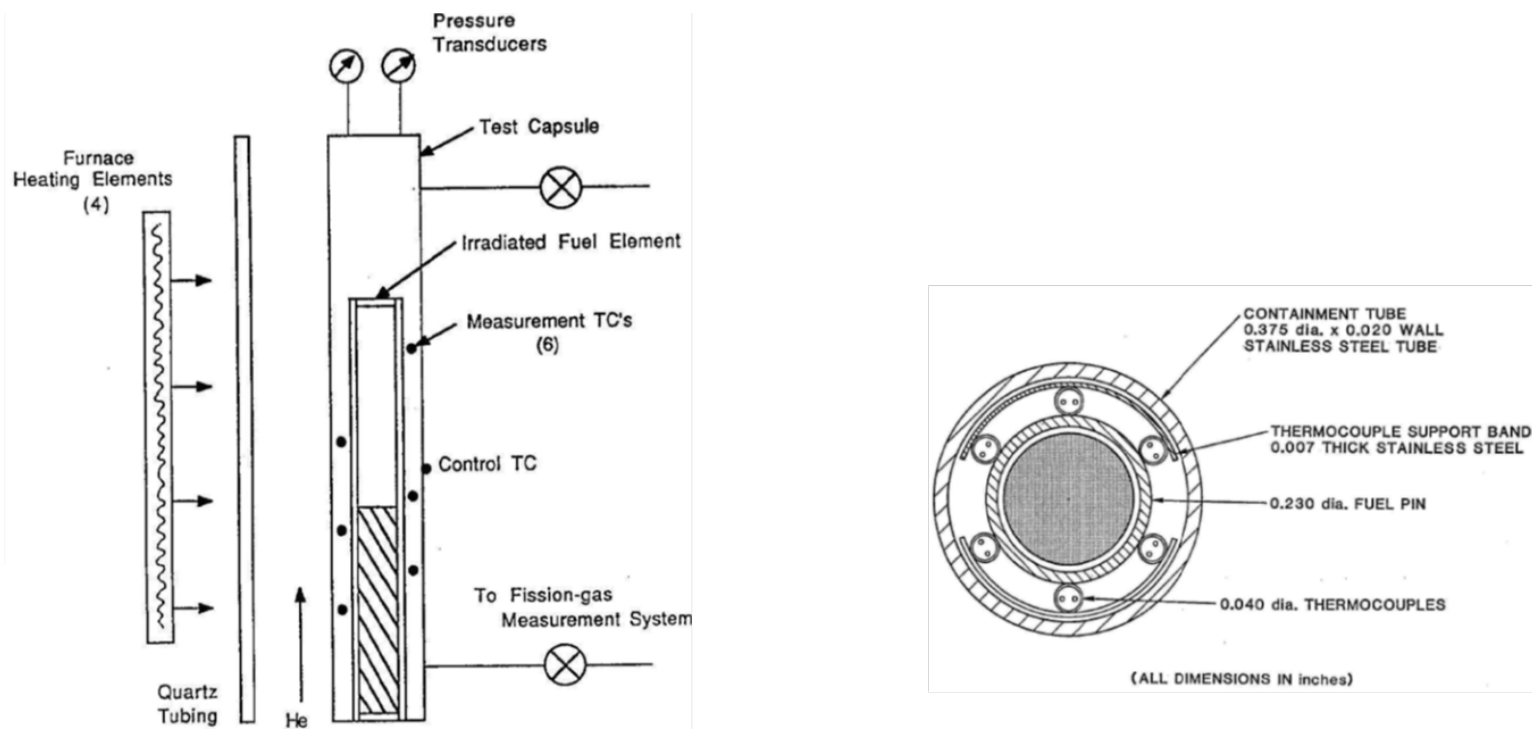

Figure 5: Schematic of Whole Pin Furnace [10].

\subsubsection{WPF Experimental Procedures}

The WPF tested the intact, full-length EBR-II irradiated fuel pins contained inside a $1.2 \mathrm{~m}$ long stainless-steel test capsule that was evacuated and sealed before testing. The pin was overheated by an infrared furnace with a 25" heating zone at the center (14" uniform zone). Steady temperatures up to $1100{ }^{\circ} \mathrm{C}$ were achievable, with short-term bursts up to $1650{ }^{\circ} \mathrm{C}$, and with heating ramp rates up to $30^{\circ} \mathrm{C} / \mathrm{s}$. Placement of the pin at furnace centerline gave it a prototypical EBR-II axial temperature gradient. The computer-controlled furnace maintained the prescribed test temperature based on feedback from a control thermocouple welded to the outside of the test capsule. Pin breach, or failure, was monitored by two pressure transducers inside the capsule. Six thermocouples in the annulus between fuel pin \& test capsule recorded temperatures throughout the test. The experimental setup also included in-cell gas retention as well as ex-cell gas sampling and measurement.

The following information was collected for the WPF tests: axial temperature profiles, capsule temperature history, fuel pin temperature history (at six locations along the pin), capsule pressure, and video imaging of the test. Pre- and post-test characterizations at HFEF and AGHCF included axial gamma scans and neutron radiography to determine fuel pin \& test capsule relative dimensions, and destructive metallographic examinations were done after the test to determine the extent of fuel-clad chemical interaction. Collected gas samples were also analyzed for some samples.

\subsection{2 $\underline{\text { WPF Testing Matrix }}$}

The WPF test matrix is shown in Table 2. Seven tests were conducted on intact, EBR-II irradiated fuel pins. The first four tests, FM-1 through FM-4, were to establish the cladding integrity margins. Pins were overheated and "run to breach," and pin failure modes identified. Test FM-5 was a 
simulation of the most severe EBR-II design basis accidents, the UN-1 LOF (loss of flow) event [11]. The pin was subject to a temperature ramp routine representative of the UN-1 event in order to prove that the pin could survive the event. Tests FM-6 and FM-7 tested if the pins could survive extended times at intermediate temperatures. The fuel condition was examined after each test in longitudinal and cross-sectional images, showing pin breach location, fuel restructuring, alloy redistribution, and cladding penetration.

\begin{tabular}{|c|c|c|c|c|c|c|c|}
\hline Test ID & Fuel/Cladding & $\begin{array}{l}\text { Fuel } \\
\text { Pin }\end{array}$ & S/A & $\begin{array}{c}\text { Plenum/Fuel } \\
\text { Vol. Ratio }\end{array}$ & $\begin{array}{c}\text { Pk. B/U } \\
(\mathrm{a} / \mathrm{o})\end{array}$ & $\begin{array}{c}\text { Test Temp } \\
\left({ }^{\circ} \mathrm{C}\right)\end{array}$ & $\begin{array}{c}\text { Test } \\
\text { Time }(\mathrm{m})\end{array}$ \\
\hline & \multicolumn{7}{|c|}{ Cladding Integrity Margin Tests (to Failure) } \\
\hline FM-1 & U-10Zr/HT9 & T418 & X425 & 1.0 & 3.0 & 820 & 67 \\
\hline FM-2 & U-19Pu-10Zr/HT9 & T461 & $X 425$ & 1.0 & 3.0 & 820 & 112 \\
\hline FM-3 & U-19Pu-10Zr/HT9 & T680 & $\mathrm{X} 430 \mathrm{~A}$ & 1.4 & 2.2 & 820 & 146 \\
\hline FM-4 & U-19Pu-10Zr/HT9 & DP-22 & $\mathrm{X} 441 \mathrm{~A}$ & 1.5 & 11.3 & 770 & 68 \\
\hline \multicolumn{8}{|c|}{ Element Survivability Tests } \\
\hline FM-5 & U-19Pu-10Zr/HT9 & DP-15 & $\mathrm{X} 441 \mathrm{~A}$ & 1.5 & 11.4 & $\begin{array}{l}4^{\circ} \mathrm{C} / \mathrm{s} \text { ramp } \\
\text { to } 780 \text {; cool }\end{array}$ & 3 \\
\hline FM-6 & U-19Pu-10Zr/HT9 & DP-39 & $\mathrm{X} 441 \mathrm{~A}$ & 1.0 & 11.3 & $650-670$ & 2160 \\
\hline FM-7 & U-19Pu-10Zr/316 & T539 & X429B & 1.0 & 13.3 & $650-670$ & 2160 \\
\hline
\end{tabular}

Table 2: WPF Test Matrix [10].

\subsubsection{WPF Key Results}

The constant temperature run-to-breach tests FM-1 through FM-4 demonstrated a large safety margin for cladding failure in both low and high burnup metallic fuel pins subjected to high temperature transients. The UN-1 Loss of flow event, for example, is less than 2 minutes in duration, and measured failure times of the pins were over an hour. Proof test FM-5 showed that the EBR-II Mark-V driver fuel can survive the most severe EBR-II design basis accident transient (UN-1) without failing and with minimal cladding damage. It exhibited no melting, and cladding wastage was found to be comparable to wastage seen in the steady-state sibling pin. That is, no incremental cladding penetration was found as a result of the UN-1 transient test. Long-time tests FM-6 and FM-7 demonstrated that high-burnup U-19Pu-10Zr metallic fuel can operate for 36 hours at temperatures up to $650^{\circ} \mathrm{C}$ without eutectic formation at the fuel-cladding interface. The pin failures were found to be the result of cladding thinning by eutectic formation and cladding overstress by fission gas pressure loading. A cross-section of a failed fuel pin from test FM-2 is shown in Figure 6. It shows the location of cladding breach, cladding eutectic penetration depth, and areas of escaped and re-solidified fuel outside the cladding after pin failure. 


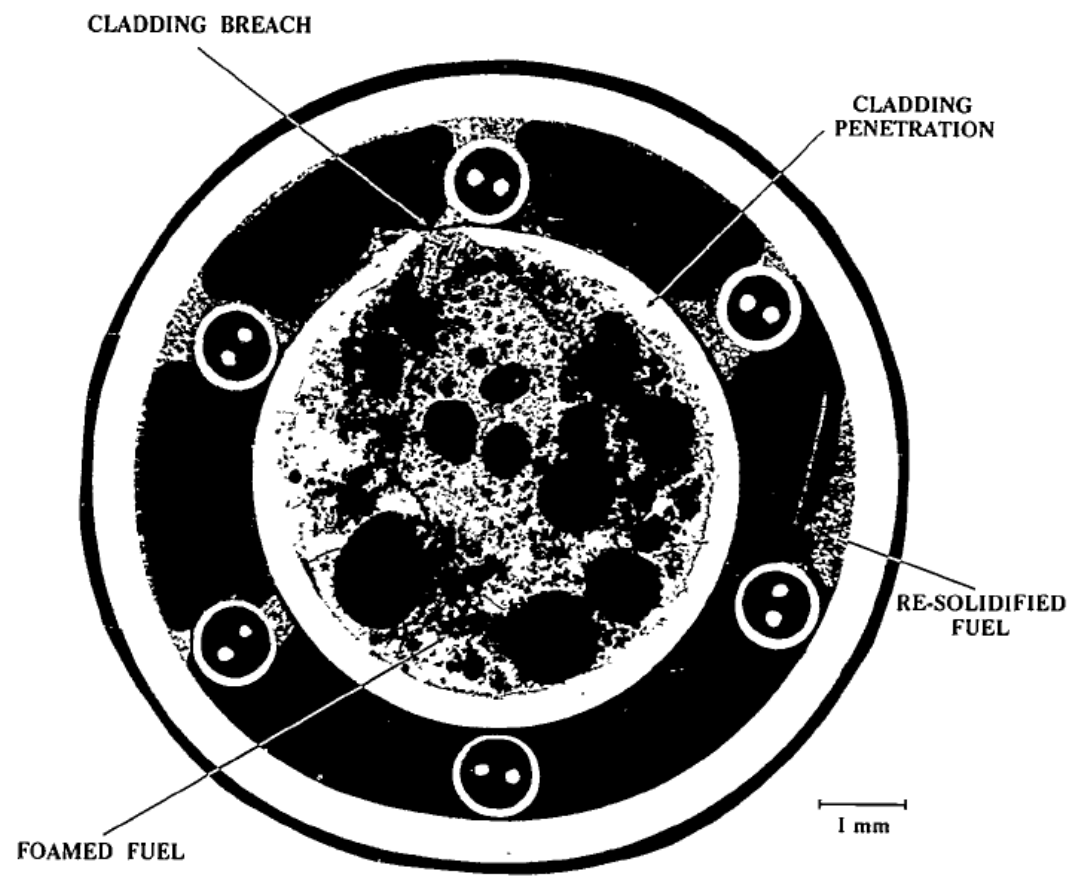

Figure 6: Cladding breach in WPF test FM-2 [10].

\subsection{Summary Results of Out-of-Pile testing program}

The findings that came out of the FBTA and WPF out-of-pile furnace tests contribute to the safety case for metallic fuels in fast reactor applications. For most transient events, liquid phase formed only in the region of the sample where there was preexisting cladding wastage (from the steadystate irradiation). Only if the transient was particularly prolonged could the eutectic reaction progress further, into previously unaffected areas of the cladding.

For brief, "design basis" transients (of durations seconds to minutes), there was no evidence of eutectic formation below $775{ }^{\circ} \mathrm{C}$ in even the "worst case" EBR-II pins (with the highest power, cladding temperatures, and burnups). For longer transients beyond design basis events, eutectic formation was seen in the worst-case pins at $\sim 675{ }^{\circ} \mathrm{C}$. For pins that were subject to less aggressive irradiation conditions, the eutectic formation temperature was another $50^{\circ} \mathrm{C}$ higher. While the irradiation conditions pins experienced in EBR-II affected the eutectic threshold temperature, it was found they did not affect the rate of transient-induced cladding wastage. It is worth noting that the "worst case" pins in EBR-II presented a particularly challenging set of conditions, as the highest power, cladding temp, and burnup are experienced at the same location, near the fuel top, because of the flat axial power profile. These fuel survivability results are highly relevant for designers intending to use metallic fuels for modern reactor designs. This work has therefore have aimed to create an easy-to-use database that enables designers to quickly find the test and records most relevant to their design work. 


\section{DATABASE CONTENT}

This section describes the information and records contained in the out-of-pile furnace test database. The database contains details and description of each test conducted in the FBTA and WPF test apparatuses. This includes test objectives, experimental parametric information, and sample descriptions, as shown in Figure 7.

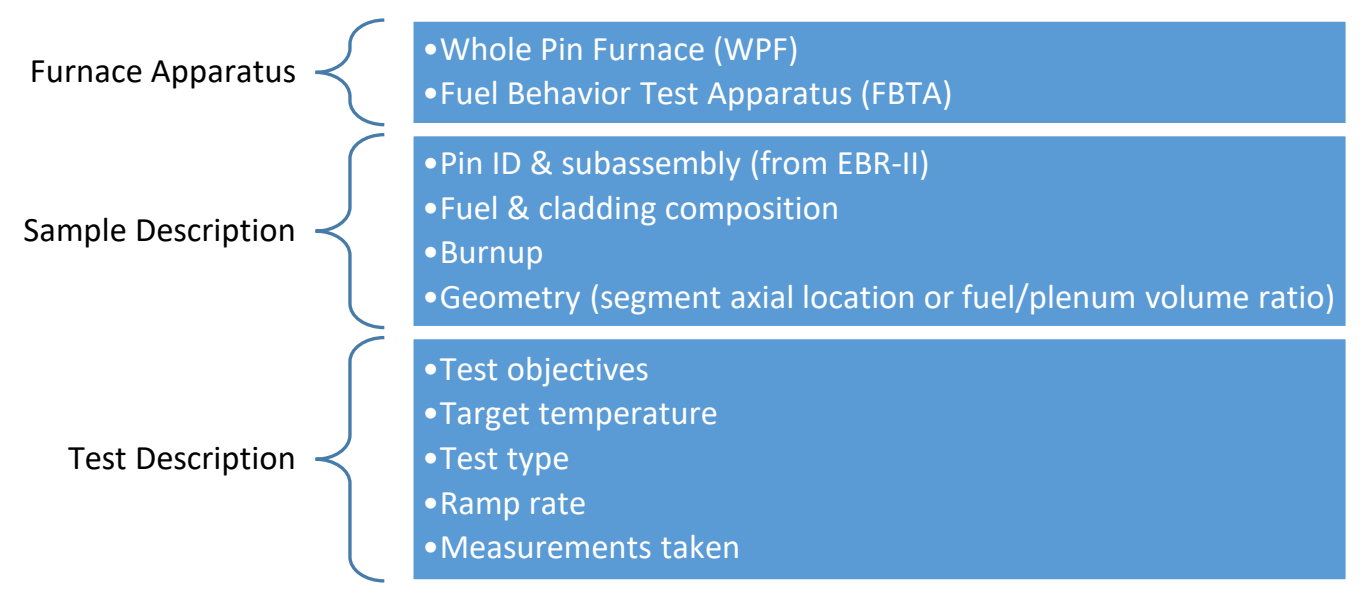

Figure 7: Summary of Furnace Test Information available in OPTD.

For each of these tests, there exists a collection of related records ranging from informal, internal memoranda to formal programmatic progress reports, conference submissions, and other publications. The experiment (and post-experiment) records include sample transport, shipping, and storage records, fuel pin sectioning diagrams, metallographic images of the sectioned samples, and experimenter reports. Experimental schematics, design documents, and test procedures are also included. Each record is tagged according to the categories and descriptors listed in Figure 8.

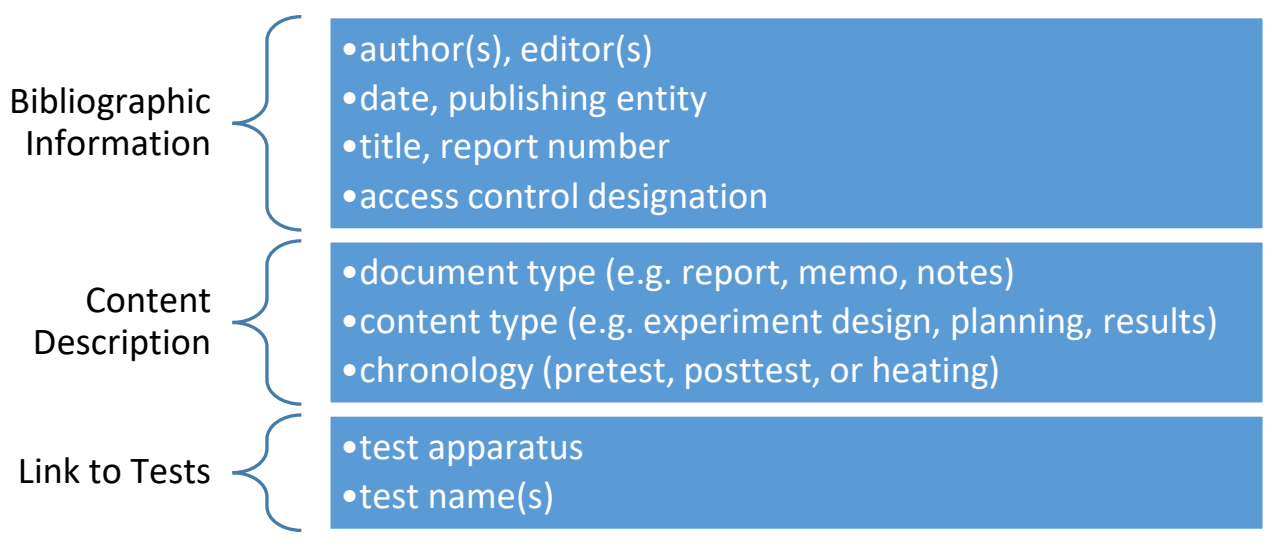

Figure 8: Record Descriptors in the database.

Hard copy records pertaining to the out-of-pile furnace tests were collected, scanned, and saved as text-searchable pdf files in a digital archive. It should be noted that all located records have been archived, however, it is likely that more records may be found in the future. The collection is 
certainly incomplete, but it is currently unknown which records may still exist in a recoverable form somewhere at the laboratory. An exhaustive search has been conducted for the AGHCF records and data-books, and 61 of 62 were located and scanned for inclusion in the database. If and when additional unique records surface, they will be added to the archive. It is expected that further active searching will not lead to locating any more records, but rather new discoveries may be made when someone is cleaning out an old office one day, and the database is capable of accommodating additions without any need for significant down time. At the time of this report, no numerical, raw instrument readout data has been located, nor have any video records of the WPF tests. If and when these data are found, they will be added to the database. 


\section{DATABASE STRUCTURE}

For the purposes of this section, the term "database" refers to an ordered and indexed library of information. It exists as a digital archive of scanned and saved records of documents (in pdf form) and accompanying spreadsheets of tables storing the related metadata. The database can be thought of as having three main components: A table of metadata describing the out-of-pile furnace tests, a digital archive of records relating to those tests, and a table describing the records.

\subsection{Test Information}

Each furnace test has a unique name (of the form "yy-\#\#” for the FBTA tests and "FM-\#” for the WPF tests). The test table stores a list of the tests, indexed by name. Each test is represented by one row of the table, and each metadata item in Figure 7 corresponds to a column (or columns) in the table. The metadata is linked, such that tests with specific characteristics can be related to other tests with similar characteristics (e.g., tests conducted on the same fuel/clad combination).

\subsection{Records Information}

The scanned and saved digital records were logged in a table and indexed by the filename. Each file is represented in its own row of the table, and metadata (shown in Figure 8) describing the type of record, the experiment to which it pertains, and bibliographic information is recorded in columns. The records metadata is also linked, such that a record with specific characteristics can be related to other records with similar characteristics (e.g., all test design specifications).

\subsection{Future Content}

While the pin identification for each sample is indicated in the database, it is not presently linked to the full subassembly and irradiation history information provided in existing EBR-II databases. It may be advantageous to link directly to subassembly and irradiation history information in the future, but this would require coordination between other databases to avoid redundantly reproducing the subassembly information locally. 


\section{WEB INTERFACE}

For consistency, the web interface for OPTD is nearly identical to that used for TREXR [4]. A home page contains general information about the database and instructions for requesting access. Users are asked to authenticate before they are able to access the search pages for tests and records. Help links with further instructions are provided throughout.

\subsection{Site map}

If a user wants to explore what is available, the "About” page provides an overview of the database as well as a description of the out-of-pile testing program. For a user seeking information about a particular kind of test, they can search for a test by any of the described metadata filters. For example, a user could search for a ramp-and-hold heating test conducted on a U-10Zr/HT9 segment. The results would display the tests that meet the selected filter criteria. Clicking on the test name brings the user to a test details page that provides abbreviated test summary information and links to related test records. A similar search can also be done for records. A site map is shown in Figure 9.

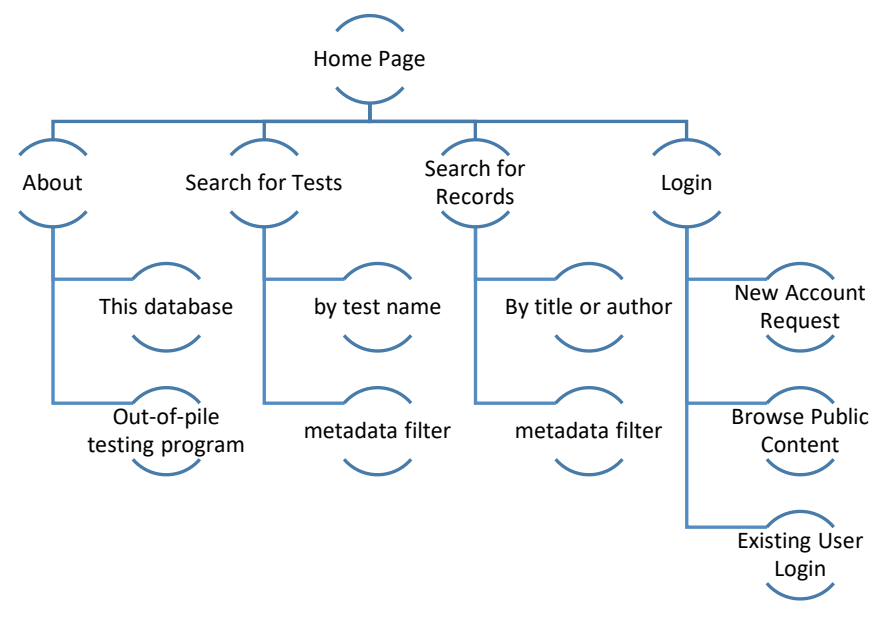

Figure 9: OPTD Site Map.

\subsection{Access Controls}

At this time, because so few of the test records are presently open access, database user accounts will only be granted to DOE users. Once a significant number of the records are approved for distribution, the application can open access to all users using the tiered access system used for TREXR, described in ANL-ART-127 [12]. 


\section{ACKNOWLEDGEMENTS}

Significant effort was made by Mike Billone to locate and identify the appropriate legacy AGHCF data books containing records of the out-of-pile tests. The work of scanning and saving digital copies of these records was performed by Katherine Hunnicutt. 


\section{REFERENCES}

[1] "EBR-II Fuels Irradiation \& Physics Database," Argonne National Laboratory, 2018. [Online].

[2] "EBR-II Physics Analysis Data Base (PADB)," Argonne National Laboratory, 1994. [Online].

[3] "EBR-II Test Database," Argonne National Laboratory. [Online].

[4] "TREXR: The TREAT Experimental Relational Database," [Online]. Available: https://www.trexr.anl.gov/.

[5] J. M. Kramer and T. H. Bauer, "Fuel Damage During Off-Normal Transients in Metal-Fueled Fast Reactors," in Proceedings of the 1990 International Fast Reactor Safety Meeting, Snowbird, Utah, CONF-900804-20, 1990.

[6] Y. Y. Liu, H. C. Tsai, D. A. Donahue, D. O. Pushis, F. E. Savoie, J. W. Holland, A. E. Wright, C. August, J. L. Bailey and D. R. Patterson, "Whole-Pin Furnace System: An Experimental Facility for Studying Irradiated Fuel Pin behavior Under Potential Reactor Accident Conditions," in Proceedings of the 1990 International Fast Reactor Safety Meeting, Snowbird, Utah, CONF-900804-24, 1990.

[7] H. Tsai, "A Versatile Apparatus for Studying Irradiated Fuel Behavior," in Winter Meeting of the American Nuclear Society, San Francisco, CA, CONF-891103-54, 1989.

[8] H. Tsai, "Fuel/Cladding Compatibility in Irradiated Metallic Fuel Pins at Elevated Temperatures," in Proceedings of the 1990 International Fast Reactor Safety Meeting, Snowbird, Utah, CONF-900804-9, 1990.

[9] L. Leibowitz, A. G. Hins, R. V. Strain, H. Tsai and G. L. Hofman, "Compatibility of U-PuZr Alloy Fuel with Stainless Steel Cladding," ANL-IFR-109, 1989.

[10] "Integral Fast Reactor Program Annual Progress Report FY1993," Argonne National Laboratory, ANL-IFR-244, Argonne, Illinois, 1994.

[11] Y. Y. Liu, H. Tsai, M. C. Billone, J. W. Holland and J. M. Kramer, "Behavior of EBR-II Mk-V-type fuel elements in simulated loss-of-flow tests," Journal of Nuclear Materials, vol. 204, pp. 194-202, 1993.

[12] C. Tomchik, A. Oaks, H. Connaway and A. Wright, "External Access to the TREXR Database," ANL-ART-127, 2018. 


\section{Argonne}

\section{Nuclear Engineering Division}

Argonne National Laboratory

9700 South Cass Avenue, Bldg. 362

Argonne, IL 60439

www.anl.gov 